\title{
Prisonisering - en ubekreftet «jernlov» om sosialt liv bak murene $^{P}$
}

\author{
Av Leif Petter Olaussen (l.p.olaussen@jus.uio.no) ${ }^{2}$
}

\begin{abstract}
Norwegian sociology of law and criminology have asserted for decades that imprisonment leads to prisonization, i.e., that prison conditions create a normative climate in prisons that is detrimental to resocialization and may even increase the probability of recidivism. Whether this is true is an important scientific and political question. The current review, designed to corroborate the prisonization hypothesis, ultimately fails to support it.
\end{abstract}

\section{Innledning}

Bruk av fengselsstraff tilsier at vi bør ha best mulige kunnskaper om hvilke virkninger den har. Ett viktig spørsmål i denne forbindelse er om fengselsstraff bidrar til å øke snarere enn å redusere kriminalitetsproblemer, ved at denne straffen øker tilbakefallet til ny kriminalitet. I norsk kriminologi og rettssosiologi har det i en hel generasjon blitt hevdet at kriminologisk forskning ${ }^{3}$ viser at fengselsstraff har en slik virkning. Fullstendig mangel på faglige forbehold om holdbarheten til den forskningen som norsk kriminologi og rettssosiologi har vist til, formidler at vi her står overfor en «jernlov» om livet bak murene. I det følgende vil jeg presentere og drøfte forskningen som angivelig skal underbygge dette, og jeg vil supplere med forskning som ikke har blitt tatt med i nevnte faglitteratur. Siden det verken er mulig eller nødvendig å ta opp alle sider ved forskning som jeg mener er aktuell for temaet, vil jeg gi til kjenne hvilke kriterier jeg har lagt til grunn når jeg har valgt ut det jeg vektlegger her:

1) Prisoniseringsteorien må gjøres kjent, og være gjenstand for kritisk vurdering, og vurderes i lys av konkurrerende eller supplerende teori.

2) Momenter som er viktige for hvor vidt det kan trekkes holdbare konklusjoner av empiriske undersøkelser av teorien må omtales og drøftes. Det gjelder særlig forskningsdesign, metode- og analyseopplegg.

* Title in English: Prisonization: An unconfirmed "iron-law" for social life in prisons 
3) Undersøkelser som ikke understøtter teorien kan ikke utelates, men må tas med.

4) Overføring av kunnskaper som ser ut til å være gyldige i et samfunn til et annet kan være utilrådelig fordi viktige samfunnsforhold, som institusjonaliserte ordninger, kan være og virke svært forskjellig. Slik kunnskapsoverføring forutsetter derfor nøye vurdering.

I den følgende presentasjon og omtale av forskning som har blitt påstått å bekrefte at fanger blir prisonisert, og at tilbakefall derfor må forventes, har jeg lagt disse fire elementære kravene til grunn.

\section{Prisoniseringsteorien}

Begrepet 'prisonization' stammer fra den amerikanske sosiologen og fengselsdirektøren Donald Clemmer (1958). Den norske oversettelsen, prisonisering og verbet å prisonisere, ble introdusert av Johan Galtung (1959). Så vidt jeg kjenner til, er det bare Clemmer som har lagt fram noe som kan kalles en teori om prisonisering. Med dette sikter han til at mennesker som settes i fengsel, kan bli preget av oppholdet der. For det første vil alle fangers daglige liv og atferd i anstalten bli preget av de kunnskaper som fanger etter hvert får om dagliglivets rutiner og måten livet $\mathrm{i}$ anstalten er organisert på, og for det andre lærer de at de har en underordnet og sterkt regulert posisjon i forhold til de ansatte, det fordres at de må akseptere og innrette seg deretter. Denne formen for prisonisering kalte Clemmer universell prisonisering fordi slik pregning antas å gjelde alle fanger, og når fengselsoppholdet varte inntil ett år, antok han at dette ville være den eneste eller mest sannsynlige formen for prisonisering. For fengselsopphold som varte mer enn ett år, antok han at det også ville være en mulighet for at fangene ville internalisere verdier, normer, dogmer, oppfatninger, etc. som er særegne for fangesamfunnet. Slik prisonisering kalte han kulturell prisonisering. Clemmer antok at det var mulig at langtidsfanger vil gjennomgå en assimilasjonsprosess i fengslet som var en parallell til det som fant sted i det amerikanske samfunnet utenfor murene, når immigranter ble assimilert i den amerikanske kulturen (s. 299). Da kunne de opphøre å være polakker, dansker, norske, osv. og bli amerikanere fordi og hvis de internaliserte, tok opp i seg og levde etter, verdier, normer, dogmer, oppfatninger, etc. som var typisk amerikanske. Clemmer antok at kulturell prisonisering (bare omtalt som prisonisering i det følgende) som regel bare ville inntreffe hvis fengselsstraffen varte mer enn ett år, men han anså ikke en slik følge som verken nødvendig eller sterkt sannsynlig. Sannsynligheten for prisonisering ville være betinget av mange viktige forhold som jeg har listet opp i Oppstilling 1. 
Oppstilling 1: Faktorer som i følge Clemmer er sarlig viktige for at fanger vil bli kulturelt prisonisert

\begin{tabular}{|c|c|c|}
\hline \multirow[t]{2}{*}{ Særlig viktige faktorer: } & \multicolumn{2}{|c|}{ Grad av kulturell prisonisering ${ }^{*}$} \\
\hline & Lav & Нøу \\
\hline 1 Fengselsstraffens lengde ${ }^{*}$ & $\begin{array}{l}\text { Kortvarig, men som regel over } \\
\text { ett år }\end{array}$ & Flere år \\
\hline $\begin{array}{l}2 \text { Fangens sosiale relasjoner } \\
\text { før fengsling }\end{array}$ & $\begin{array}{l}\text { Adekvate relasjoner som har } \\
\text { skapt positiv sosialisering }\end{array}$ & $\begin{array}{l}\text { Inadekvate mht. å skape en sta- } \\
\text { bil personlighet, men gir grunn- } \\
\text { lag for sterke overbevisninger } \\
\text { og særegen lojalitet }\end{array}$ \\
\hline $\begin{array}{l}3 \text { Positive relasjoner til per- } \\
\text { soner utenfor fengslet }\end{array}$ & $\mathrm{Ja}$ & Nei \\
\hline $\begin{array}{l}4 \text { Evner og åpenhet for grup- } \\
\text { perelasjoner i fengslet }\end{array}$ & Nei, er avvisende & $\mathrm{Ja}$ \\
\hline $\begin{array}{l}5 \text { Aksept av dogmer og nor- } \\
\text { mer i fangesamfunnet }\end{array}$ & Nei, er avvisende & Blind/ nesten blind aksept \\
\hline $\begin{array}{l}6 \text { Tilfeldig plassering i } \\
\text { fengslet }\end{array}$ & $\begin{array}{l}\text { Sammen med andre som ikke } \\
\text { er fullstendig integrert i feng- } \\
\text { selskulturen og ikke har leder- } \\
\text { egenskaper }\end{array}$ & $\begin{array}{l}\text { Sammen med personer med like } \\
\text { oppfatninger som han selv }\end{array}$ \\
\hline $\begin{array}{l}7 \text { Åpenhet for deltakelse i } \\
\text { gambling og avvikende } \\
\text { seksuell atferd }\end{array}$ & Avstår fra & $\mathrm{Ja}$ \\
\hline
\end{tabular}

Kilde: Clemmer (1958) s. 301-302.

* Ved straffer inntil ca. ett års varighet, vil det som regel bare være tale om universell prisonisering, antok han.

Den helt sentrale forutsetningen for at en fange skulle bli prisonisert, var imidlertid at fangen deltok i og var knyttet til det Clemmer kalte en 'prison-primary group', en primærgruppe av fanger. Men dette impliserer ikke at han mente at fangesamfunnet var et normativt homogent og vel integrert sosialt fellesskap. Selv om andre hadde hevdet dette, ville han få fram at fengslet ikke er et kollektiv av likesinnede, godt integrert personer, men tvert imot er en diffus ansamling av personer med et sosialt liv preget av manglende strukturell klarhet, ustabile sosiale relasjoner, opposisjon, konflikter og sosial oppløsning (s. 297). Stor grad av enighet var fraværende i fengslet på grunn av utbredt individualisme. I tillegg til kløften mellom ansatte og innsatte i fengslet, nevner Clemmer (s. 295-296) ni ulike dimensjoner som dannet grunnlag for sosiale skiller mellom fangene, og han konkluderte: «Denne undersøkelsen har funnet og rapportert atskilling belegg 
for å vise at konsensus, solidaritet, vi-følelse blant fanger har blitt overdrevet tidligere.» (s. 322). Han viste til at kollektiv handling forekommer meget sjelden $\mathrm{i}$ fengsler (s. 290) og nevnte (s. 292-293) at det ikke en gang var kollektiv buing i hans fengsel de tre gangene en fange ble henrettet i den elektriske stol. De få gangene at skadeverkspregete opprør fant sted, var det bare en liten del av fangene som deltok, nevnte han også. Dette fant han helt logisk i lys av at det var få felles verdioppfatninger blant fangene, slik at den sosiale kontrollen dem i mellom var lite effektiv, mens fengslets formelle og maktbaserte kontroll var langt sterkere. Og han så fengslets behov for sterk og maktbasert sosial kontroll som begrunnet i fangesamfunnets grunnleggende heterogenitet, og at fangene ville ut, mens fengslet var pålagt å holde dem innelåst. Fangene hadde heller ikke vært lovlydige tidligere $\mathrm{i}$ et mindre strikt miljø enn et fengsel er, og det kan ikke forventes at de vil oppføre seg fredelig mens de er innesperret (s. 150), mente han.

Selv om det aller viktigste strukturelle trekket ved fengslet er den dype (men likevel ikke helt absolutte) kløften mellom ansatte og fanger, var det nest viktigste strukturelle trekket «forekomsten av spontant formede primære og semiprimære grupper, som, i kraft av å være strukturer, skaper mulighet for at sosiale prosesser finner sted.» (s. 296), mente Clemmer. De sosiale prosessene som var viktige, var først og fremst de som var knyttet til uformelle sosiale grupper av fanger, som han kalte fengsels-primærgrupper og semi-primærgruper. Slike grupper var ofte knyttet til ulike fritidsaktiviteter i fengslet. Prosesser både blant gruppemedlemmene og fanger som ikke var med, kunne dreie seg om konkurranse om å få være med i en gruppe, av og til om konflikter som følge av at noen hadde blitt tatt inn i gruppen, og noen ganger endte det med en etterfølgende konflikt og innlemming $\mathrm{i}$ en annen gruppe. På denne måten var grupper grunnlag for sosiale prosesser, og i dem kommer både positive og negative holdninger til uttrykk. De forårsaker både at tilknytninger skapes og går i oppløsning (s. 296297). På denne måten vil fanger bli kjent med sosiale normer som er viktige blant dem, fordi fangene selv og deres uformelle ledere håndhever viktige normer. Selv om bredden i normative oppfatninger som det var enighet om blant fangene, var mye smalere enn utenfor fengslene, nevner Clemmer fem verdioppfatninger som det rådet en viss enighet om (s. 151). Den oppfatningen som var mest universelt utbredt blant fangene, var ønsket om frihet fra innesperringen. Normen at fanger ikke skulle hjelpe fengselsansatte, var ikke like universelt utbredt, men det var likevel stor enighet om den. Mindre utbredt var idealet om at fanger skal være lojale mot hverandre, og det var ganske utbredt enighet om at fanger som blir fysisk eller mentalt syke må få omsorg og behandling. Han fant også mye snakk blant fanger om betydningen av å være lojal mot sin egen familie. 
Primærgrupper av fanger må imidlertid ikke oppfattes som stabile, varige og tett integrerte enheter. De var løsere grupper som oppsto og gikk i oppløsning, og det var heller ikke slik at alle fangene i Clemmers fengsel deltok i slike grupper. Han fant at 40 prosent av fangene på ingen måte var integrert i grupper med sterke sosiale relasjoner mellom deltakerne, 42 prosent deltok i nokså overfladisk gruppeliv, uten å være genuint knyttet til en spesifikk gruppe. Bare omkring 18 prosent var knyttet til et lite antall andre fanger (2-7 personer) på en slik måte at gruppens struktur og funksjon var tilnærmet lik det man finner i samfunnet utenfor murene. Men selv i mange av disse gruppene var det mangel på grunnleggende samhold (s. 112). I grove trekk var det slik, skriver han (s. 113) at de som inngikk i slike primærgrupper av fanger var yngre, noe mer intelligente og mer kriminelle enn menn som ikke deltok i grupper. Dette er naturligvis en viktig grunn til at Clemmer ikke hevdet at kulturell prisonisering ville gjelde alle fanger.

Den faglige bakgrunnen for at tilknytning til primærgruppe og primærgruppekontroll i fengslet står så sentralt i Clemmers tenkning, er hans hans faglige bakgrunn i chicagoskolens sosiologi (med Robert E. Park, Ernest W. Burgess og Charles H. Cooley). Det er gjennom samliv med andre at individet blir en person, vår personlighet er for en stor del gruppeskapt, og Clemmer viser eksplisitt til Cooley når det gjelder primærgruppene (s. 112), blant annet at her skapes det en «vi»-oppfatning som følge av gjensidig sympati og identifikasjon med hverandre. I primærgruppen kommer den enkelte under gruppens innflytelse og kontroll, selv om gruppen kan preges både av innbyrdes konkurranse og uenigheter. Siden Clemmer ville forstå det samfunnet som fengslet etter hans oppfatning utgjorde, var det selvsagt for ham å undersøke grupper og fangenes gruppetilhørighet $\mathrm{i}$ fengselet. - Forekomst av en lang rekke spesielle ord og uttrykk, til sammen 1063 forskjellige, som fanger brukte i fengslet og som Clemmer kalte argot, tolket han også som en indikasjon på at det fantes en egen fangekultur i fengslet.

Clemmer påpekte at det han kalte fangers prisoniseringsprosess ikke forløper på en ordnet, lineær måte, men har en tendens til å være irregulær, til og med syklisk. Han skriver:

«Noen menn blir i høyeste grad prisonisert, eller nær det, men så forkaster de hele denne orienteringen og viser verken ved atferd eller holdninger at noen integrering i fengselssamfunnet har funnet sted. De sklir ut av gruppelivet. De ignorerer tegn og dogmer og faller inn i dagdrømmeri eller dorskhet, eller de blir «ensomme menn». Så etter måneder eller år i denne rollen kan de gjenoppta gruppetilhørighet og vise atferd som andre prisoniserte fanger.» (s. 302). ${ }^{4}$ 
Prisonisering fører altså ikke til en stabil, varig tilstand, slik for eksempel vaksinasjon mot hepatitt B gir. Resultatet av prisonisering vil være like lite stabil som tilknytningen til primærgrupper vil være, og den vil være betinget av mange forhold som kan endre seg i løpet av en langvarig soning. Derfor må både grad av og tempo i prisoniseringsprosessen studeres individuelt, mente Clemmer, og kvantitative metoder må derfor være forbudt (prohibited), skrev han (s. 303). Dette forbudet har imidlertid ikke blitt etterlevd av noen som har forsøkt å teste teoriens holdbarhet, så vidt jeg kjenner til.

Hvilken oppfatning hadde Clemmer om prisoniseringens betydning for fangers tilbakefall til ny kriminalitet? - Han hadde ingen data som kunne belyse dette, men han trodde ikke at det ville være noen nødvendig sammenheng mellom fangers grad av prisonisering og deres mulighet til å leve et liv mindre preget av kriminalitet enn før soning av fengselsstraff. Han skrev:

«Ingen formodning er intendert om at det vil være høy korrelasjon mellom ekstremverdier for prisonisering og kriminalitet. Det er fullt mulig at en fange som ikke blir integrert i fengselskulturen kan være og kan fortsette å være mye mer kriminell enn en fange som blir fullstendig prisonisert.» (s. 302)

Dette standpunktet er ikke overraskende siden han oppfattet fangers deltakelse i fengsels-primærgrupper som både begrenset og ustabil, slik at prisoniseringen også ville være det. Dessuten er ingen av de fem verdioppfatningene som Clemmer mente preget fangekulturen, direkte knytte til kriminalitet, slik at det er vanskelig å se at internalisering av disse verdiene (altså prisonisering) skulle ha noen betydning for livsførselen etter endt soning. I et foredrag Clemmer holdt ti år etter at boka var publisert, gjentok han sitatet ovenfor, og poengterte at man fortsatt ikke visste presist hvilken rolle fengsel har som årsak til fortsatt kriminalitet, men han tilføyde at kriminelle oppfatninger fanger hadde ved innsetting kunne bli forsterket i fengslet:

«Det kan tenkes at en kriminell oppfatning som personen brakte med seg inn i fengslet ble mer intens som følge av prisonisering, og forble et personlig potensiale da han ble løslatt.» ${ }^{5}$

Formidlingen av hans teori har ikke alltid vært preget av samme grad av nøkternhet. 
Galtung 1959

Johan Galtungs (1959) grunnlag for sin studie av Oslo kretsfengsel var at han sonet 165 dager i fengsel i 1954-55 fordi han nektet å utføre 6 måneder ekstra vernepliktig sivilarbeid som militærnektere på den tiden ble ilagt. I soningstiden gjorde han en del undersøkelser, og så innhentet han senere supplerende intervjudata fra 35 fanger og 20 betjenter, samt spørreskjemadata fra 30 betjenter i samme fengsel i november-desember 1956. Han kjente Clemmers bok og noe annen amerikansk fengselsforskning, men testet verken Clemmers eller andres teori. Galtung var imidlertid begeistret for begrepet prisonisering. Det er ypperlig, konstaterte han (s. 120), ${ }^{6}$ uten å tilkjennegi hva han syntes om teorien til Clemmer, men Galtung så trolig få likhetspunkter mellom Oslo kretsfengsel og det fengslet Clemmer hadde beskrevet. I Oslo kretsfengsel fant Galtung bare «en viss egen fengselssjargong, men ikke mange spesielle fengselsuttrykk», bare noen få uttrykk som «tyster», «monse», «bli sendt vestover», «sending», «Tåkeheimen», «Gamlehjemmet» og alle øke- og kjelenavn på betjenter og ledelse farger språket i noen grad, men for øvrig skiller språket seg lite fra vanlig, saftig uttrykksform i et utpreget mannssamfunn,» (s.139). - Mens Clemmer bygde sin prisoniseringsteori på primærgruppesamvær mellom fangene, var Galtung sterkt opptatt av fangenes ensomhet, isolasjonen i egen celle. Den gang var det langt færre muligheter for sosial omgang enn i dag blant fanger i Oslo kretsfengsel. Men samtaler var selvsagt mulig under verkstedarbeid, ved utføring av kjøkkentjeneste, matservering, renhold av korridorer og kontorer o.l., under lufting og ved opphold på fengselssykehuset. ${ }^{7}$ Det «trykk» eller «press» som fangene var utsatt for under soningen, og som Galtung var opptatt av, gjaldt «fangens problemer når han er alene med seg selv» (s. 79), altså innelåst på sin celle. Derfor betonte Galtung sterkt fangens fritid mellom klokken 18 og 22, «fire timer til lyset blir slukket, og disse fire timene er på en måte døgnets viktigste. Det er i løpet av disse timene fangens forhold til fengslet formes - det som har hendt i løpet av dagen blir tolket inn i hans system, og alt blir satt i relasjon til oppholdet som helhet.» (s. 60-61). De fem pressproblemene (eller press-stimuli) som Galtung fremhevet, var fangens forhold til eget lovbrudd, dom og straff, verden utenfor fengslet, seksualitet og egenutvikling (s. 79). Disse press-stimuliene samtidig med at fangene var isolert fra sine primærgrupper i det fri, kunne føre til at de ble prisonisert, tenkte han (s. 241). Den enkelte fange måtte finne en løsning på det sterke psykiske presset som disse stimuliene utgjorde, og Galtungs teoretiske forklaringsmodell forutsatte at det fantes tre mulig løsninger: å forholde seg rasjonelt; å bruke vanlige psykologiske forsvarsmekanismer; eller atferdsmessige fluktmekanismer. Dessuten fremsatte han en hypotese om at det kunne finnes normer i fangekulturen som 
minsket presset og gjorde det lettere å bruke de nevnte forsvarsmekanismene (s. 136). Forbud mellom fanger mot å snakke om egen familie, og å spørre om andres lovbrudd, kan være eksempler på slike normer. I en reflekterende avslutning på boka skrev han imidlertid at sosialisering inn i fangesamfunnet

«løser fangens umiddelbare problem, og det vil få prioritet for mennesker i fangens frustrerte situasjon framfor å løse de langsiktige problemene med tilpasning til det norske samfunnet. Og i fangesamfunnet som de sosialiseres inn $\mathrm{i}$ er sosiale verdier satt på hodet, skylden lagt på politi og rettsvesen og høyere lag i samfunnet, osv. (...) Alt dette hindrer fangen i å ta opp sitt eget problem - lovbruddet han har utført - og det er intet i fengselsritualet som hindrer ham i å skyve dette problemet i bakgrunnen. I gamle dager var dette fengselsprestens rolle, men det later til at presterollen er blitt mer sekularisert og at intet annet er kommet $\mathrm{i}$ stedet for å fylle denne funksjonen» (s. 241).

Galtungs tanker om prisonisering var altså helt andre enn Clemmers. Galtung fryktet at fangekulturen forhindret at fanger forholdt seg konstruktivt og langsiktig til sine egne kriminelle handlinger som de hadde blitt ilagt straff for, og derfor fryktet han at fangekulturen må bidra til å bringe fangen lengre vekk fra resosialisering. Han foretok imidlertid ingen systematisk utforsking av hvilke normer fangekulturen eventuelt håndhevet, men formulerte det han selv kalte «et forslag til normsystem» (s.135-138). Ingen av hans 15 spesifiserte forslag til normer uttrykker aksept for kriminalitet.

På den ene side hadde Galtung ingen tro på at fengselsstraffen virket resosialiserende, selv om han ikke trodde at fengslet direkte skaper eller vedlikeholder kriminalitet. Men indirekte kan det tenkes at det virker slik, mente han, ved at fanger integreres i et miljø som de kan oppsøke etter løslatelsen. De får kontakter. «Og aller viktigst er formodentlig at sosialiseringen inn i fangesamfunnet legger grunnlaget (hvis det ikke var der fra før) for en sterk asosial eller antisosial holdning» (s. 137). - Også andre steder kommer det fram at Galtung regnet med at mange fanger hadde en asosial eller antisosial holdning når de kom inn i fengslet, altså at slike holdninger ble importert inn i anstalten, en oppfatning han var kjent med fra amerikansk fengselsforskning.

Det er nok fortsatt en ganske vanlig oppfatning at fanger får kontakt med andre under soning av fengselsstraff, og at fanger som soner sammen senere begår kriminalitet sammen. Men dette er en antakelse som knapt er undersøkt forskningsmessig. Lena Roxells (2011) undersøkelse er et meget sjeldent unntak. Hun undersøkte om 3930 svenske fanger som hadde sonet straff sammen ble mistenkt for å ha begått lovbrudd sammen i løpet av en oppfølgingsperiode som varte omkring to og et halvt år. Selv om 73 prosent av fangene var politiregistrert som mi- 
stenkt for nytt lovbrudd i løpet av oppfølgingsperioden, var det bare 2 prosent (70 personer) som var mistenkt for lovbrudd sammen med en de hadde sonet fengselsstraff sammen med. En del av disse 70 personene kjente dessuten hverandre før de sonet straff sammen. Hvis en andel på mindre enn 2 prosent er noen lunde representativ for hvor hyppig fengslene etablerer nye «brothers in crime», må vel fengslene kunne karakteriseres som lite effektive også i så måte?

\section{Wheeler 1961}

I norsk rettssosiologi og kriminologi fremstilles Stanton Wheelers (1961) prisoniseringsundersøkelse som en særlig viktig bekreftelse av Clemmers teori. Undersøkelsen bygger på data som ble innhentet ved hjelp av spørreskjema i et fengsel med omkring 750 fanger i alderen 16-30 år som kunne ha begått alle former for kriminalitet bortsett fra handlinger som kunne medføre dødsstraff. Av dem ble 295 valgt ut tilfeldig for å delta i undersøkelsen, hvorav 237 faktisk deltok, men alle besvarte ikke alle spørsmål. I spørreskjemaet var det fem spørsmål som var ment å måle fangenes grad av prisonisering, eller internalisering av fangekulturen. For å kunne vurdere om fangenes oppfatninger var avvikende, besvarte også fengselsbetjenter de spørsmålene som skulle måle prisonisering. Wheeler målte altså fangers grad av prisonisering ved at han sammenlignet fangenes svar med fengselsbetjenters svar på spørsmål om fem hypotetiske fengselssituasjoner ${ }^{8}$ som ble grunnlag for en tredelt indeks for konformitet (høy, middels og lav) med fengselsbetjentenes oppfatninger. Fangene med lavest grad av konformitet antas å være de som i størst grad var prisonisert.

Men fangene besvarte Wheelers spørreskjema bare én gang. Derved sier det seg selv at undersøkelsen hadde et særdeles svakt metodisk design med hensyn til å kunne si noe som om hvor vidt fangenes holdninger endret seg i løpet av soningstiden. Wheeler var selvsagt klar over at han uttalte seg om utviklingsforløp over ganske lange soningstider, uten at han hadde tidsseriedata å bygge på. Han konkluderte derfor med eksplisitt forbehold og påpekte at problemstillingene han ville belyse krever paneldata, det vil si tidsseriedata der de samme fangene blir intervjuet i flere faser av soningsforløpet. ${ }^{9}$ Men Wheelers forbehold har aldri blitt formidlet i norske fremstillinger av hans arbeid. Derved har hans konklusjoner framstått som langt bedre underbygd enn de er og slik han selv presenterte dem. ${ }^{10}$

Som en nødløsning på dette problemet antok Wheeler at han kunne dele fangene i tre grupper ut fra hvor de befant seg i soningsforløpet av den dommen de hadde, og på den måten skaffe seg fiktive eller konstruerte tidsseriedata: 
- De som var tidlig i soningsfasen (hadde sonet mindre enn 6 måneder)

- De som var i en sluttfase (hadde mindre enn 6 måneder igjen)

- De som var i en midtfase (dette var en restkategori i forhold til de to andre gruppene)

Wheelers hovedfunn er presentert i tabell 1. Det framgår av kolonnen for «Lav» konformitet at prosentandelen øker fra 9 prosent blant de som var i tidlige fase i soningen, til 14 prosent for de som var i midtfasen, og til 25 prosent for fangene som var i sluttfasen av soningen. I supplerende analyser fant han at det var slik både for de som sonet sin første fengselsstraff og for dem som hadde sonet tidligere. Dessuten tydet data på at prisoniseringen var sterkest de første månedene $\mathrm{i}$ fengsel, og Wheeler fant støtte i sine data for at prisoniseringen kunne være en følge av fangers uformelle kontakter med hverandre, i tråd med Clemmers prisoniseringsteori, vel og merke hvis Clemmers fiktive tidsseriedata er valide data om fangers reelle utviklingsforløp under soningen. Samtidig viser de nevnte prosentandelene at bare en forholdsvis liten del av fangene kan sies å være sterkt prisonisert, også det i samsvar med Clemmers antakelse.

Tabell 1: Fangenes grad av konformitet med de fengselsansattes normative oppfatninger etter hvilken fase i soningsforløpet fangene er i. Prosent

\begin{tabular}{lrrrrr}
\hline Fase i soningsforløpet: & \multicolumn{3}{c}{$\begin{array}{c}\text { Grad av konformitet med } \\
\text { fengselsansattes normer }\end{array}$} & Totalt & N \\
\cline { 2 - 4 } & Høy & Middels & Lav & & \\
\hline Tidlig fase $(<6$ mnd) & 47 & 44 & 9 & 100 & 77 \\
Midtfase & 21 & 65 & 14 & 100 & 94 \\
Sluttfase $(>6$ mnd) & 43 & 33 & 25 & 100 & 40 \\
\hline Totalt & \multicolumn{7}{l}{} & & & 211 \\
\hline Chi $=20.48$ p $<0.001$ 4df, gamma $=-0.21$ &
\end{tabular}

Kilde: Wheeler (1961 tabell 7, s. 706). 
Figur 1: Fangenes grad av konformitet (høy, middels og lav) med de fengselsansattes normative oppfatninger etter hvilken fase $i$ soningsforløpet fangene er $i$. Prosent

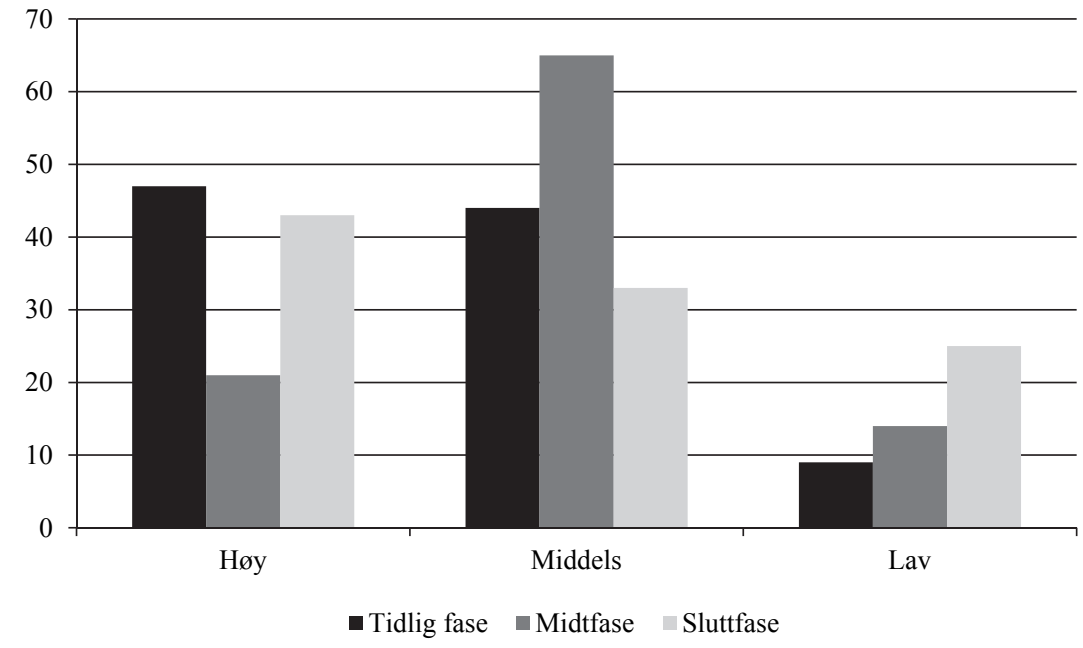

I norsk sammenheng er det imidlertid Wheelers U-kurve som har blitt fremhevet, se de tre spylene til venstre i figur 1. U-kurven viser til de fangene som Clemmer fant hadde høy grad av konformitet med de fengselsansattes normer, og som vel må karakteriseres som prisonisert i meget liten grad. I tidlig soningsfase hadde 47 prosent av fangene høyt normativt samsvar med de fengselsansatte, i midtfasen var prosentandelen bare 21 prosent, og så økte den til $43^{11}$ prosent i sluttfasen. Når Wheeler antok at han hadde data om et utviklingsforløp over tid, stemte de overens med en antakelse om at fangekulturen har noe innflytelse på (noen) fanger. En del fangers normative oppfatninger reduseres i midtfasen av soningen fra høy til middels konformitet. Men denne endringen var midlertidig for nesten alle, siden oppfatningene for de fleste ble høyt konforme igjen i sluttfasen av soningen. Wheeler antok at dette viser at ganske mange fanger kanskje gjennomløper et variabelt normativt forløp gjennom soningstiden som følge av at de skifter tidsperspektiv under soningen. De starter som en fange med lang tid til (prøve)løslatelse og ender som en fange med å ha kort tid igjen. Midt i soningsforløpet vil de være lengst borte fra friheten utenfor murene, og derfor mest påvirket av fangekulturen. Men hvis man tolker U-kurven som utviklingsforløp over tid, slik 
Wheeler gjorde, er U-kurven også i samsvar med Clemmers antakelse om at mange fanger bare blir svakt prisonisert, og at prisonisering er en ustabil, skiftende og til og med syklisk prosess. Noen kan bli prisonisert for så å kaste disse holdningene av seg, mente han jo. - Alternativt kan Wheelers data og U-kurven tolkes som målinger av holdningsmessig potensiale for konflikt mellom fanger og fengselsansatte. Det er lavt i første fase av soningen, men tiltar etter hvert som fangene for alvor blir kjent med og merker restriksjonene i fengslet. Men når omkring halvdelen av soningen er over, innstiller flere og flere seg på at de snart skal løslates, vekk fra fengselsregimet, og da reduseres potensialet for konflikt i sluttfasen og blir omtrent som i begynnelsen.

Wheeler hadde ingen data om fangenes atferd etter løslatelse, men diskuterte ${ }^{12}$ muligheter for at prisoniseringen kunne virke negativt. En særlig potent virkning kunne inntre hvis fangers selv-oppfatning blir varig endret som følge av et budskap om å være forkastet og degradert, noe som er implisitt i fangestatusen, mente han. I så fall ville løslatte møte verden utenfor med et selvbilde preget av angst og manglende tro på seg selv, slik til og med «tøffe» fanger preges av like før løslatelse, og de vil trekkes mot samvær med andre tidligere dømte, ikke så mye for å fortsette med kriminalitet, som for å finne sosial omgang med noen som er støttende - men selvsagt kan det bli mer kriminalitet ut av dette, tenkte Wheeler.

Fire undersøkelser som ikke har blitt trukket inn

1. Atchley og McCabe 1968

Atchley og McCabed undersøkelse var en replikasjon av Wheeler (1961), også når det gjaldt detaljer i analyseopplegget. De hadde data fra et fengsel med 856 fanger, 16-33 år gamle, og de sonet for det meste relativt korte straffer for mindre alvorlig kriminalitet. De valgte tilfeldig ut femti prosent av fangene og har data fra 426 fanger, nesten dobbelt så mange fanger som Wheeler hadde i sitt utvalg, og fangenes alder var ganske lik i de to undersøkelsene. På ett punkt er det en slående likhet mellom resultatene i de to undersøkelsene: I begge undersøkelser er det svært like fordelinger av fangene på de tre gruppene sterkt konforme, middels konforme og lite konforme (Atchley og McCabe 1968 tabell 8, s. 780). Den gruppen fanger som kan tolkes som mest prisonisert, var minst $(17,6 \%)$ også i Atchley og McCabes undersøkelse, men prosentandelen lite konforme fanger økte $i k k e$ systematisk med soningstiden lengde, slik Clemmer hadde antatt og Wheeler hadde funnet. Etter å ha gjennomført de samme analysene som Wheeler, måtte Atchley og McCabe konkludere med at de verken fant noen støtte for prisoniseringshypotesen, eller Wheelers U-kurve. De fant ingen sammenheng mellom fase i soningsforløpet og andel fanger med sterk konformitet. «Det syntes 
ufattelig at det ikke skulle finnes en eneste likhet mellom våre funn og det Wheeler hadde funnet, men det er nøyaktig hva som hendte» (s. 177). Selv om en mindre del av fangene i deres undersøkelse kunne tolkes som prisonisert, konkluderte de som følger:

«Denne undersøkelsen kan verken underbygge Clemmers eller Wheelers teorier om utvikling av prisonisering, og vi gjorde ingen funn som kan understøtte Wheelers hypotese at selvoppfatningen vil synke før løslatelse fra fengsel.

Kort sagt, resultatet av undersøkelsen vår legger eksisterende teorier om den sosiale dynamikk i fengselslivet $\mathrm{i}$ grus. Vi vet at prisonisering finnes $\mathrm{i}$ fengsler, men våre gamle forklaringer på den synes å være heller svake, eller i det minste ikke universelt gyldige» (s. 784-785).

Også de ønsket mer forskning - basert på paneldata - og de påpekte at det ville være av betydning å foreta oppfølgingsstudier etter løslatelse for å finne ut om prisonisering virkelig hadde betydning for fangenes resosialisering. Det hadde ingen undersøkt.

Fra begynnelsen av 1960-tallet kom viktige kritiske innvendinger mot Goffmans (1961) teori om at totale institusjoner bryter ned menneskers selvoppfatning (mortifikasjonsprosesser ${ }^{13}$ ) og bygger opp en slags institusjonsmennesker (ved hjelp av et privilegiesystem ${ }^{14}$ ). Også Sykes (1958) deprivasjonsteori ${ }^{15}$ om fanger møtte nå motbør. Denne teorien gikk ut på at fengsler krenker fangenes menneskelige verdighet, integritet og selvbilde, og at fengselslivets deprivasjoner medfører sterke lidelser (pains of imprisonment). Fanger vil derfor svinge mellom å etablere sosiale bånd til hverandre - et fellesskap av lojalitet, felles mål, gjensidig respekt og opposisjon mot fengselsregimet (altså et fangesamfunn) - eller å gå inn i en slags alles krig mot alle der det viktigste er å oppnå personlige fordeler. Deprivasjonsteorien bygde på funksjonstenking der det ble lagt til grunn at institusjonsklienters tenke- og væremåte er en funksjon av interne institusjonsregimer som først «nullstiller» og deretter «restrukturerer» fanger og andre institusjonsklienter til å bli andre personer enn de var ved innsettingen. Irwin og Cressey (1962) var blant de som tidlig kritiserte denne tenkemåten. De mente at den funksjonalistiske fengselsforskningen som bare glattet over muligheten for at fangene brakte en kriminell delkultur inn i fengslene, hadde fått for stor vekt, og at «man har oversett den dramatiske virkningen som atferdsmønstre utenfor fengslet har på fangenes atferd i hvilket som helst fengsel.» ${ }^{16}$ Man bør ikke overse det faktum at det finnes kriminelle subkulturer utenfor fengslene, og heller ikke at mange fanger har flere fengselsopphold bak seg, noen har institusjonsopphold tilbake til tidlig barndom, og at dette gjør at de «bringer med seg et ferdig 
sett av atferdsmønstre som de så anvender i en ny situasjon, (...) en klar forståelse av fangers atferd kan ikke oppnås bare ved å se «fengselskulturen» eller «fangekulturen» som et isolert system om bare springer ut av fengselsmessige forhold.» ${ }^{17}$ I denne sammenhengen er det verdt å merke seg at Irwin og Cresseys argumentasjon også støttet seg til en analyse som Wheeler $(1962)^{18}$ hadde gjort av sine norske fengselsdata. ${ }^{19}$ Irwin og Cressey (1962 s. 153) viste til at Wheeler verken hadde funnet noen normativ orden eller sosiale bånd blant de norske fangene, slik man hadde funnet i amerikanske fengsler. Dessuten hadde Wheeler antydet at rådende, funksjonelle tolkningene av fangekulturen i amerikanske fengsler ikke er generelt gyldige, samt at generelle trekk ved det norske samfunnet blir importert inn i fengsler og i stor grad virker som en hindring mot at en solidarisk fangegruppe blir dannet. - Thomas Mathiesen fant ingen solidarisk fangekultur i Ila sikringsanstalt, men «censoriousness» blant Ilafangene (1965 s. 72-76). De kritiserte fengselsforhold og fengselsledelse med utgangspunkt i normative standarder som var viktige i det norske samfunnet ellers, som rettferdighet og menneskelighet. Forutsetningene for Ilafangenes kritikkatferd kan derfor forstås som importert fra samfunnet utenfra, både de normative standarder som de anvendte, og fangenes oppfatning at kritikk er legitimt. Rose Giallombardo (1966a jfr. 1966b) fant heller ikke prisonisering i kvinnefengslet hun undersøkte. Hun argumenterte for at atferd i mannsfengsler som ble tolket som prisonisering var utslag av mannsroller etablert utenfor fengslene og altså ble importert inn, mens en importert kvinnerolle ikke la til rette for tilsvarende fengselsatferd blant kvinner.

\section{Cline 1968}

Hugh F. Cline hadde i samarbeid med Wheeler analysert det omfattende fangematerialet som Wheeler hadde samlet i danske, finske, norske og svenske fengsler i begynnelsen av 1961. Dette var også data fra bare ett tidspunkt. Cline forsøkte likevel å undersøke om noen av de to teoriene, deprivasjons- eller importteorien, så ut til å være gyldig for nordiske fengsler. En test av importmodellen forutsetter at man kjenner fangenes grad av integrering i et kriminelt miljø før de ble fengslet, men Cline hadde ikke data om det. Derfor benyttet han tre proxyindikatorer bygd på opplysninger han hadde om fangene og følgende antakelser: Det vil være mest sannsynlig å finne personer som var integrert $i$ et kriminelt miljø blant fanger som: i) tidligere hadde sonet fengselsstraff; ii) hadde vært plassert i barneverninstitusjon; og iii) var yngst ved første gangs arrestasjon. Clines analyser viste at negative holdninger blant fangene i nordiske fengsler var i overensstemmelse med de tre nevnte antakelsene. 
En test av deprivasjonsteorien forutsetter at man har valide mål for alle former for deprivasjoner som fanger kan være utsatt for. Clines datasett hadde bare data for sosial deprivasjon, altså inngrep i eller begrensinger av fangers mulighet for kontakt med andre. Han benyttet opplysninger om seks slike restriksjoner til å lage en indeks for sosial deprivasjon for hvert av de 15 fengslene. Denne indeksen viste seg å være negativt korrelert $(-0.36)$ med fangenes negative holdninger til personalet, og når en atypisk finsk institusjon ble utelatt fra analysen, ble den negative korrelasjonen enda sterkere (-0.76). Den empiriske sammenhengen var altså motsatt av det man forventer hvis deprivasjonsmodellen er holdbar, og Cline konkluderte at det ikke var støtte for deprivasjonsteorien, eller det aspektet som ble undersøkt, sosial deprivasjon. Dessuten fant han en positiv sammenheng mellom fangers kontakt med omverden og antipersonell holdning, ${ }^{20}$ altså at antipersonellholdninger var mest utbredt i fengsler der fangene hadde best kontakt med omverden. Sett under ett kan dette bety, mente Cline, at det er relativ deprivasjon som fører til antipersonellholdninger blant fangene. Det er ikke (mengden av) sosiale restriksjoner i seg selv som har betydning for forekomst av antipersonellholdninger blant fangene. Men slike restriksjoner får (stor) betydning når anstaltene er så åpne mot verden utenfor at livet der blir fangenes målestokk for hvordan de opplever fengslets restriksjoner på deres kontakt med omverden. - Kanskje det altså er slik at fangene «importerer» det de anser som gyldig målestokk for sosial kontakt?

\section{Balvig 1969}

Flemming Balvig analyserte både det danske materialet om fem anstalter som Wheeler hadde samlet, samt et nytt materiale fra 1968 for fire anstalter hvorav to også inngikk i Wheelers materiale, men heller ikke han hadde paneldata. Et hovedspørsmål for Balvig besto i å forsøke å undersøke om det var grunnlag for å tro at fangesamfunnet er preget av solidaritet mellom fanger og å være vel integrert i normativ forstand, samt om fanger er fiendtlig innstilt til formelle anstaltnormer. Balvigs data tyder på at dette i stor grad er myter (s. 129ff) som dels skyldes at fengselsforskere har trukket slutninger om fangenes normer ut fra hva de har svart på spørsmål, ikke ut fra observasjon av hvordan fanger faktisk handler, og dels skyldes mytene at det hersker betydelig usikkerhet blant fanger om hva andre fanger mener og foretrekker. Resultatet blir at fangesamfunnet preges av flertallsmisforståelser (s. 134). Fanger utfører handlinger som de feilaktig tror at svært mange andre fanger mener er riktige, men ikke dem selv. Dette er en side av fengselslivet som ble berørt av både Clemmer og Wheeler, og som Linda Kjær Minke (2012) tar opp i sin avhandling. ${ }^{21}$ 
I tråd med Clemmers antakelse at prisonisering er en følge av interaksjon i fangegrupper undersøkte Balvig om fangenes interaksjonsfrekvens med andre fanger var korrelert med ulike fengselskomponenter, deriblant fangenes holdning til anstalten, oppholdet der, anstaltens personale og andre fanger. «Korrelationer forekommer så sjældent og er så lave, at man kan tilskrive dem tilfældigheder. ... Vi har ingen iagttagelser over tid i dette materialet, men ved siden af den ret løse interaktionsstruktur på et givet tidspunkt, som vi har konstateret her, er der grund til at forvente, at man over længere tid på linje med Mathiesens [1965] resultater vil finde, at interaktionen har en relativt tilfældig, variabel og ikke stabil natur. Mathiesen fandt, at de dannede grupperinger hurtigt opløstes, og dette kunne ikke blot henføres til løsladelser» (Balvig 1969, s. 138-139). Dette svekker rimeligvis sannsynligheten for at prisonisering blir skapt og formidlet ved interaksjon $\mathrm{i}$ (primær)grupper av fanger. I Balvigs analyser av det danske materialet ble Wheelers U-kurve gjenfunnet i bare én av anstaltene, Herstedvester (Balvig 1969, s. 159-161).

\section{Wheeler 1969}

I en oversiktsartikkel om sosialisering i fengselsanstalter som Wheeler (1969) skrev omtrent samtidig med at Clines analyser av nordiske data ble gjort, viser Wheeler til at importmodellen og deprivasjonsmodellen fortsatt var hovedforklaringer på fangekulturer i amerikanske fengsler. Han viste også til Wheeler (1961), men var ukjent med at Atchley og McCabes replikasjon ikke bekreftet et eneste av hans funn. Dessuten viste han til egne data fra 1961 om fangene i Botsfengslet i Oslo. Etter hans oppfatning var dette fengslet svært likt det amerikanske fengselet som Sykes (1958) studerte og som førte til at han trakk den generelle konklusjonen at fangekulturen oppstår som følge av «pains of imprisonment». Wheeler, som ikke virket overbevist om denne sterkt mekaniske teoriens generelle holdbarhet, en slags jernlov om fangers sosialisering, fant støtte i sine botsfengselsdata for å være skeptisk til at Sykes teori kunne generaliseres til fengsler hvor som helst. Blant botsfengselsfangene fant han på den ene side de deprivasjoner som var vanlig å finne i studier av fengsler, og som ble hevdet å være følger av konstant nærvær av fangevoktere, fravær av kvinner, angrep på selvaktelse og materiell deprivasjon. Men på den annen side var det ikke mulig å finne noe som kunne minne om en fangekultur. Sosiale bånd og normative oppfatninger som kunne sveise fanger sammen, var svært svake i Botsfengslet. Selv brudd på fangers norm om at de ikke skal tyste på hverandre, ble ikke alltid strengt sanksjonert. Indikasjoner på organisert opposisjon mot de ansatte manglet, og knyttneveslagsmål blant fanger forekom svært sjelden. Et svært lavt voldsnivå blant fangene i 
Botsfengslet var en særlig markant forskjell til det som var typisk i mange lignende amerikanske fengsler. Fangesjargong som både Clemmer og Sykes hadde vektlagt, fant han heller ikke mye av. Blant fangene i Botsfengslet var det nesten ikke mulig å finne ord og uttrykk som var særegne for et fangemiljø. ${ }^{22}$ Den eneste klare normen i amerikansk fangekultur som også i høy grad fantes i Botsfengslet, var at fanger ikke skulle spørre hverandre om hvilket lovbrudd de var dømt for, og heller ikke spørre om deres liv forut for fengslingen.

Da Wheeler forsøkte å forklare forskjellene mellom fanger i amerikanske fengsler og botsfengselsfangene, og at Botsfengslet manglet en fangekultur, til tross for vanlige fengselsdeprivasjoner, trakk han inn en rekke ulike momenter:

1) Botsfengselsfangene hadde gjennomsnittlig straffer på drøyt ett år, mens vanlige gjennomsnitt i USA var to til fem år i lignende fengsler.

2) Fengsel brukes sjeldnere i Norge. Det kan bety at fengslene derved ikke får de fangene som er best til å organisere og til å skape gruppebasert opposisjon i fengslene.

3) Fangene i Botsfengslet var mer isolert - i sin egen celle - enn det som var vanlig i amerikanske fengsler. (Mens $43 \%$ av fangene i Botsfengslet svarte at de ikke hadde fått en venn i fengslet, var det tilsvarende tallet omkring $10 \%$ i tilsvarende amerikanske fengsler.)

4) Siden Norge ikke var så preget av materiell overflod som det amerikanske samfunnet, kunne det tenkes at nokså like deprivasjoner i norske fengsler ble opplevd mindre sterkt av norske fanger enn av de amerikanske. En antakelse om relativ deprivasjon kan forklare at en fangekultur oppstår i USA, men ikke i Norge, under like depriverende fengselsforhold.

5) Men den mest plausible forklaringen på forskjellen i fangekultur mellom USA og Norge mente Wheeler var å finne i ulike forskjeller i generell kultur utenfor fengslene som fanger i begge samfunn brakte med seg inn (altså importerte) $i$ fengslene. ${ }^{23}$

Den viktigste forskjellen i så måte var fraværet av voldelig og antagonistisk kriminell subkultur i det norske samfunnet. Få norske lovbrytere brukte våpen, og det norske politiet er ubevæpnet. Profesjonelle lovbrytere fantes nesten ikke i Norge, og organisert kriminalitet var sjelden, også blant unge. Kort sagt, tanken blant kriminelle om å bruke vold som kontrollmiddel oppstår ikke i Norge. Til og med boksing, som var en meget populær fritidsaktivitet i amerikanske fengsler, skapte overraskelse og forferdelse blant norske botsfengselsfanger. Amerikanske fangers vektlegging av å være tøff og smart, og deres tilbøyelighet til å se sam- 
funnet i et «vi-de»-perspektiv, er typisk nokså fraværende blant de norske fangene (s. 1013). Det var totalt fravær i Norge av amerikansk slumkultur, og det norske samfunnet er relativt homogent, preget av begrenset lagdeling, skrev Wheeler. Sammenlignet med amerikanere, fant han også at nordmenn generelt var mer innadvendte, med tendens til å være isolert, og han antok at dette også kunne motvirke etablering av sosiale bånd i fengselet. Verken nordmenn flest eller norske fanger søker å etablere vide sosiale nettverk. De går helst sin egen vei og opptrer helst alene.

\section{Bondesons undersøkelser}

Den siste undersøkelsen som både Finstad og Gjetvik (1980) og Mathiesen (2007 og 2011) bruker som belegg for at fengsler virker prisoniserende, er en omfattende undersøkelse av svenske fengsler og ungdomsinstitusjoner utført av Ulla Bondeson (1974). Sammenlignet med tidligere undersøkelser var Bondesons undersøkelse langt mer omfattende. Hun inkluderte 13 ulik institusjoner i sitt materiale - sju verneinstitusjoner for ungdommer, to ungdomsfengsler, ett kvinnefengsel, to mannsfengsler og en interneringsanstalt - med til sammen 965 innsatte.

Det er særlig tre indekser som Bondeson hadde lagd og brukte i sin undersøkelse av ulike negative påvirkningsprosesser i institusjonene, som er av interesse her, en kriminalitetsskala (KKK), argot-kunnskap, og solidaritet med andre innsatte. Ingen av indeksene ble kalt prisonisering, men hun skrev at av de tre indeksene er det solidaritet med andre innsatte som ligner mest på Wheelers mål for prisonisering. ${ }^{24}$ Det er jeg enig i. Forskjellen mellom Wheelers prisoniseringsindeks og Bondesons solidaritet består i at Bondeson brukte tre scenarier som de innsatte tok stilling til $\mathrm{i}$ et spørreskjema, mens Wheeler brukte fem. Argotkunnskap anså hun som en indikator på individuell tilknytning til en kriminell subkultur. ${ }^{25}$ I en tidligere undersøkelse ${ }^{26}$ på en verneskole for unge jenter hadde hun funnet at argot-kunnskaper skilte tydelig mellom en gruppe kriminelle og kontrollgrupper, og at argot-kunnskaper samvarierte med kriminell atferd og kriminelle normer, samt med tid de unge hadde tilbrakt $\mathrm{i}$ institusjonen.

Etter min oppfatning vil argot-kunnskaper ha tvilsom validitet som indikator for tilknytning til en kriminell delkultur i fengslet, med mindre argot-uttrykkene bare vil være kjent for de som har en slik tilknytning. En valid indikator forutsetter så å si at argot-uttrykkene langt på vei blir holdt hemmelig for utenforstående. Men var det slik i Bondesons tilfelle? Det er ikke mulig å vite eller vurdere fordi hun ikke gir noen oversettelse av de 40 ordene som inngikk i testen, «av hänsyn till grupper som vill betrakta argot som sitt eget språk». ${ }^{27}$ På grunn av denne hemmeligholdelsen er det også umulig å vurdere i hvilken grad ordene er knyttet 
til fengselsrelaterte forhold, eller om de for eksempel er knyttet til rus og rusmidler og andre forhold utenfor anstaltene. - Kanskje Clemmers tanker om argot er verdt å vurdere: Han kjente ikke ordenes opprinnelse, skrev han, men anså det som lite sannsynlig at mange av dem hadde oppstått i det fengselet han undersøkte. Altså må de ha kommet dit utenfra og ha vært kjent der. Han gjengir litt av et intervju med en innsatt som han betegnet som «ganske kriminell og svært intelligent.. ${ }^{28}$ Denne fangen kjente ingen argot som hadde oppstått i fengsel, med unntak for uttrykk som utelukkende er knyttet til fengselsforhold, og han mente at argot kommer til fengslene med nye fanger eller besøkende og blir lett adoptert og spredt hvis den er slagferdig eller humoristisk. - Hvis argot i stor grad er uttrykk som fanger bringer med seg inn i fengslene, hva vil da argot-kunnskaper kunne være et valid mål for? - Kanskje ikke annet enn samlet tid bak murene og stor sans for morsomme og slagferdige uttrykk, eller for tilhørighet til et kriminelt belastet miljø innenfor eller utenfor fengselsmurene. Argot-kunnskap har etter min oppfatning lav validitet som mål for prisonisering.

Med en rekke enkeltvariabler og tre indekser i stedet for bare én, dekket Bondesons undersøkelse større bredde i opplysninger om de innsatte enn det tidligere undersøkelser hadde hatt. En ytterligere prinsipiell forbedring i forhold til tidligere undersøkelser besto $i$ at Bondeson hadde opplysninger fra to tidspunkter i løpet av anstalttiden, slik at hun i prinsippet kunnet fange opp endringer. Men siden svenske fengselsdommer var så korte, var det bare to måneder mellom de to undersøkelsestidspunktene (juni og august 1970). Det virker ikke umiddelbart opplagt at et institusjons- eller fengselsopphold på to sommermåneder vil kunne prege de innsatte veldig sterkt. Jeg kjenner ingen sosialiseringsteori som sannsynliggjør store endringer på så kort tid, og undersøkelsesperioden er alt for kort i forhold til Clemmers prisoniseringsteori om fengselsstraff på ett år eller mer. ${ }^{29}$

Bondeson la til grunn at argot-kunnskaper var et mål for tilknytning til en kriminell subkultur, men det er ikke det samme som prisonisering i Clemmers forstand. Prisonisering kan bare finne sted i fengsel, mens tilknytning til en kriminell delkultur og tilegnelse av argot både kan skje i og utenfor fengsler. I den opprinnelige undersøkelsen til Bondeson (1974) ble fangenes argot-kunnskaper målt både $i$ juni og august 1970, med ulike argot-ord i de to undersøkelsene. Hvis tilknytningen til en kriminell delkultur økte i dette tidsrommet, og argot-testen er et valid mål på tilknytning til en kriminell delkultur, skulle argotkunnskapene være bedre i august enn i juni. Men det ser ikke ut til at det var slik. Gjennomsnittsverdien for riktige svar på argot-testen sank for 6 av de 13 anstaltene og økte for 7. Bare blant verneinstitusjonene for unge var det en overvekt av institusjoner (4 av 7) der gjennomsnittet på argot-testen var høyere i august enn i juni. Bondeson 
skrev selv at resultatet på argot-testene på de to tidspunktene var forbløffende like. ${ }^{30}$ Det må bety at det ikke er grunnlag for å tro at fangenes tilknytning til en kriminell subkultur var nevneverdig forandret mellom de to undersøkelsestidspunktene, og at fengselsoppholdet av den grunn ikke kunne ha betydning for tilbakefall til ny kriminalitet. Når det gjelder de fire fengselsanstaltene som inngikk i Bondesons analyse av tilbakefall ${ }^{31}$ sank gjennomsnittsverdien for argot-testen for to fengsler, Tillberga og Hall, og økte for Hinseberg og Norrtälje. ${ }^{32}$ I panelanalysen hun foretok av dikotomiserte verdier på argotestene, var utfallet bare signifikant for innsatte med kort tid i anstalten og for anstalter for ungdom og internerte, ikke for fengselsinnsatte. ${ }^{33}$ Bondesons panelanalyser av endringer mellom de to målingene viste ingen signifikante endringer for voksne fengselsinnsatte verken for kriminalitetsskalaen $(\mathrm{KKK})^{34}$ eller for solidaritetsindeksen. ${ }^{35}$

Bondesons tverrsnittsanalyse ${ }^{36}$ av hvor vidt det var sammenheng mellom hvor lenge de innsatte hadde vært i institusjonen/fengselet og argot-kunnskaper, KKKindeksen og solidaritet, ga da også et magert resultat. ${ }^{37}$ Når data for alle 965 innsatte ble analysert under rett, fant hun statistisk signifikante sammenhenger, men når samme analyser ble gjort for hver institusjon fant hun ingen signifikante sammenhenger for KKK-indeksen. For solidaritet var tre sammenhenger signifikante, hvorav bare én gjaldt et fengsel (kvinnefengslet Hinseberg). Sammenhengen mellom argot og tid $i$ anstalten var signifikant for Hinseberg og mannsfengslet Tillberga og ungdomsfengslet Mariefred, og for fem av de sju verneinstitusjonene for ungdommer. Det er imidlertid viktig å være klar over at tid i anstalten $i k k e$ dreier seg om de to månedene juni til august, men om en sammenslåing av anstalttid fra de to måletidspunktene.

Bondeson gjennomførte også ulike andre multivariate analyser ${ }^{38}$ basert tverrsnittsdata ${ }^{39}$ for de tre indeksene hun hadde lagd. Analysene har imidlertid ingen verdi når det gjelder spørsmålet om hvilke endringer $\mathrm{i}$ fangers oppfatninger som eventuelt fant sted, og Bondesons (1974 s. 514) påstand om at undersøkelsen ikke støtter Wheelers optimistiske teori - at fangers prisonisering vil avta mot slutten av soningsforløpet - er riktig bare i den forstand at hennes forskningsdesign var slik at det ikke kunne belyse dette spørsmålet i det hele tatt. Det ultrakorte tidsrommet mellom de to datainnsamlingene og bare to målinger gjør det umulig å undersøke om det var støtte for Wheelers U-kurveteori i de svenske data. En troverdig undersøkelse fordrer selvsagt et undersøkelsesdesign med paneldata fra tre tidspunkter: like etter innsetting, midt i soningsforløpet, og like før løslatelse. Det hadde Bondeson ikke, og jeg kjenner heller ingen andre undersøkelser med et slikt design. 


\section{Leif Petter Olaussen}

Femten år senere presenterte Bondeson (1989) analyser hun hadde utført for å belyse om de institusjonserfaringer som hun hadde registrert blant personene som inngikk i Bondeson (1974), hadde noen systematiske konsekvenser for deres senere kriminalitet. Data om tilbakefall hadde hun hentet fra det svenske kriminalregisteret for en periode på 10 år fram til 15. april 1981. Bondeson viser en tilbakefallsoversikt for en femårsperiode ${ }^{40}$ som viser at hun innhentet tilbakefallsdata for så godt som alle personer i den opprinnelige studien. ${ }^{41}$ For alle anstalter under ett var tilbakefallet 74 prosent, men det varierte mellom anstaltene, lavest for anstalter for kvinner og høyest for ungdomsinstitusjoner for menn. Men Bondeson (1989) omfatter ikke analyse av tilbakefallsdata for 262 innsatte i de sju ungdomsinstusjonene (training schools). Dessuten måtte 60 personer utelates på grunn av manglende informasjoner som følge av død. ${ }^{42}$ Derved inngår 656 personer i etterundersøkelsen, $67 \%$ av totalt 985 i den første undersøkelsen. De hadde sonet straff $i$ to ungdomsfengsler, et kvinnefengsel, to mannsfengsler eller en interneringsanstalt for menn, og det var disse fangene hun hadde tilbakefallsdata for i en tiårsperiode etter at de ble intervjuet første gang i 1970. Også for disse anstaltene varierte tilbakefallet mye. Det var lavest (50\%) for Tillberga mannsfengsel og høyest for ungdomsfengslene, Skenäs (85 \%) og Mariefred (94\%). Tilbakefallet for kvinnefengslet Hinseberg var $64 \%$, vesentlig lavere enn for mannsfengslene. ${ }^{43}$

Bondeson brukte overlevelsesanalyse ${ }^{44}$ til å beregne hvor lang tid det gjennomsnittlig (median) tok fra hun intervjuet fangene første gang i 1970 til de begikk den første alvorlige ${ }^{45}$ forbrytelsen etter anstaltoppholdet og som hun fant $\mathrm{i}$ strafferegisteret. Analyseresultatet viste at de seks anstaltene falt $\mathrm{i}$ to grupper, en gruppe med tre anstalter med kort (median-)tid til første tilbakefall, den andre gruppen med tre anstalter med lengre (median-)tid. Deretter foretok hun en bivariat analyse av tilbakefallsdata for fangene i hver anstalt, med åtte uavhengige variabler, deriblant de tre indeksene (argot-kunnskap, KKK-indeksen og solidaritet). For fangene i de to ungdomsfengslene (Skenäs og Mariefred) ga ingen av de åtte variablene signifikante utslag. Variabelen solidaritet lignet som sagt, mest på Wheelers prisoniseringsvariabel, men den ga ikke signifikant utslag i forhold til tilbakefall for noen av de seks anstaltene. ${ }^{46}$ For KKK-indeksen var det en signifikant sammenheng med (median-)tid til første tilbakefall bare for to anstalter (Tillberga mannsfengsel og interneringsanstalten Hall). ${ }^{47}$ Bare for fangene i én anstalt (Norrtälje fengsel for menn) fant Bondeson en positiv sammenheng mellom argot og (median-)tid til første tilbakefall.

Neste analyse som Bondeson forsøkte, var en Cox-regresjonsmodell for sensurerte data. ${ }^{48}$ Hun nevner at en grunnleggende forutsetning for denne analysen er 
at «formen på kurven som viser tilbakefall over tid for alle personer må være identiske.» ${ }^{49}$ Men hun diskuterer ikke om det er en rimelig forutsetning for det materialet hun hadde. Jeg tviler på at det er tilfelle fordi tilbakefallsforløp vanligvis er sterkt aldersbetinget, ${ }^{50}$ og det var store aldersvariasjoner i Bondesons materiale. Alder og solidaritet som hadde vært med i analysene, ble nå utelatt (fordi de ikke ga bivariat utslag for noen anstalt i den første analysen), slik at det gjensto seks variabler i disse regresjonsanalysene. Igjen ble analysen gjort anstaltvis og én og én variabel ble fjernet fra analysene når de ikke ga signifikante utslag på den avhengige variabelen, til hun hadde fire ${ }^{51}$ variabler igjen. ${ }^{52}$ Nå viste det seg av ingen av de fire variablene ga utslag for de to ungdomsfengslene, og de ble eliminert fra den siste analysen. Bare innsatte i fire anstalter for voksne er nå med, hvorav en anstalt, Hinseberg, var et kvinnefengsel. En ny analyse med fire fengsler og fire variabler ble så gjort, og nå falt variablen Recinst ut. I den endelige analysen inngikk det dermed bare tre ${ }^{53}$ uavhengige variabler. ${ }^{54}$ Denne modellen indikerte at den underliggende tilbakefallsintensiteten (recidivism intensity) som var uttrykt ved en beregnet «overlevelseskurve» for hver av anstaltene var forskjellig for de fire anstaltene. ${ }^{55}$ En test viste at de fire kurvene (underliggende tilbakefallsintensitetene) var for ulike til at de kunne reduseres til en felles underliggende intensitet for de fire fengslene. Men selv om det var slik, kunne en del av variasjonene i de fire kurvenes form forklares av de tre variablene som inngikk $i$ analysen. Analysen dreide seg altså ikke om individuelle forskjeller i tilbakefall mellom fanger, men om variasjoner over tid mellom fire fengsler, (altså aggregatstørrelser som ikke kan ha tilbakefall), i deres underliggende tilbakefallsintensitet som Bondeson hadde beregnet. Hennes konklusjon på analysen lyder slik:

«For de fire fengslenes kunne en betydelig andel av fengslene variasjon i tidsforløp for tilbakefall forklares av tre forhold, argot-kunnskap, antall dommer per år [før 1970] og kriminalitetstype, ${ }^{56}$

Bondeson hevdet $i k k e$ at dette var egnet til å fortelle noe om sammenhenger på individ- eller fangenivå. Det skyldes nok at hun var klar over at en slik konklusjon ville vært en nivåfeilslutning, ${ }^{57}$ en konklusjon om fanger bygd på analyser av kjennetegn ved fengsler. Men en advarsel mot en slik feilslutning hadde vært på sin plass fordi det kunne forhindret at lesere begikk en slik feil. ${ }^{58}$

\section{Avslutning}

Hvis man følger helt elementære faglige krav til presentasjon, drøfting og vurdering av undersøkelser som forsøker å belyse om prisoniseringsteorien er holdbar, 
er det etter min mening ikke mulig å konkludere at det er forskningsmessig dekning for å hevde at fanger blir prisonisert. Derfor er det heller ikke belegg for at prisonisering vil føre til at fengselsdømte vil fortsette å begå kriminalitet.

Men hva om jeg hadde inkludert enda mer, og ikke minst nyere, forskning? I en ny, meget omfattende og grundig presentasjon av kunnskapsstatus - hovedsakelig basert på amerikanske undersøkelser - når det gjelder tilbakefall etter soning av fengselsstraff, konkluderer forfatterne ${ }^{59}$ at det fortsatt er mangel på gode undersøkelser av hvilke virkninger fengselsstraff har på tilbakefall. Hovedfunnet deres er at majoriteten av undersøkelser viser ingen eller en kriminalitetsbefordrende virkning av fengselsstraff, men i de fleste undersøkelsene som viser det siste, er funnet ikke statistisk signifikant ut fra vanlige standarder. - Men vi kan ikke uten videre overføre dette til norske forhold, med mindre bruk av fengselsstraff, og med vesentlig kortere dommer enn de amerikanske. Det er imidlertid lite sannsynlig at gjennomgående kortere norske fengselsdommer skulle skape mer prisonisering og tilbakefall enn lengre amerikanske fengselsdommer synes å gjøre.

Den beste kunnskap vi nå kan legge til grunn, både i undervisning og forskning, er at det ikke er belegg for å hevde at prisoniseringsteorien er holdbar. I fremtidig norsk fengselsforskning bør den legges bort eller suppleres og konfronteres med importteorien. Sykes' teori om «pains of imprisonment» og Goffmans tanker om «selvets død» i fengslene, som har vært sentralt pensumstoff for norske kriminologi- og rettsosiologistudenter i mange tiår, bør utgå som troverdige faglige analyser av belastninger som soning av fengselsstraff i Norge medfører. Inntil vi har mer og bedre kunnskaper enn vi har nå, bør vi vedstå oss at vi vet særdeles lite om hvilke virkninger fengselsstraffen har. Opprettholdelse av forskningens troverdighet forutsetter at vi ikke hevder å vite mer enn vi faktisk gjør.

\section{Noter}

1. Jeg takker Liv Finstad, Thomas Mathiesen, Anders Sondrup, Thomas Ugelvik for nyttige kommentarer til et manuskriptutkast.

2. Forfatteren er professor emeritus ved Institutt for kriminologi og rettssosiologi, Universitet i Oslo. I en artikkel i dette tidsskriftet i 2004 argumenterte han for at kriminalitet bør forstås som en institusjonalisert sosial realitet som vi alle forholder oss til. Han var initiativtaker til at den felles nordiske undersøkelsen av folks holdninger til straff ble gjennomført.

3. Finstad og Gjetvik (1980) kapittel 2, s. 19-31, Mathiesen (2007) s. 76-83 og Mathiesen (2011) s.49-53. (Se også tidligere utgaver av Mathiesens to nevnte bøker). Disse arbeidene har i ulike tidsrom vært pensum for studenter ved Institutt for kriminologi og rettssosiologi, også vil være det våren 2016 .

4. Sitater fra bøker eller artikler på engelsk er oversatt av meg. 
5. Clemmer 1950, s. 319.

6. Referanse i dette avsnittet som bare er sidetall, viser til Galtung (1959).

7. Dette gjorde at $80 \%$ av fangene svarte Galtung at de snakket flere ganger daglig med andre fanger. Andre data om samhandling oppga han ikke. Galtung (1961 note 1 s. 107-108) viste imidlertid til at det var minst tre viktige forskjeller mellom amerikanske og norske fengsler. De siste er mye mindre, fangenes interaksjon er mer begrenset (nesten alle fangene er fullstendig isolert $\mathrm{i}$ to tredeler av de 168 timene i hver uke) og fangene synes å være atskillig mindre farlige enn de som er sperret inne i amerikanske fengsler. (Galtungs kursiveringer).

8. Wheeler 1961, s. 699-700.

9. Se Wheeler 1961, s. 704 og 709 .

10. I begynnelsen av 1960-tallet rapporterte også Garabedian (1963) og Glaser (1964) at de hadde funnet en U-kurve, men også deres materiale besto bare av én måling, og i likhet med Wheeler tok de forbehold fordi de ikke hadde paneldata.

11. Forskjellen på 4 prosentpoeng mellom 47 prosent og 43 prosent er opplagt ikke statistisk signifikant.

12. Wheeler 1961, s. 710-711.

13. Begrepet 'mortifikasjonsprosesser' viser til krenkelser $\mathrm{mm}$. som fører til at fangers selvoppfatning dør.

14. I fengsler har fanger svært sjelden rettigheter, men de kan (etter søknad) innvilges et gode (besøk, permisjon, prøveløslatelse og lignende) som et privilegium, og slike goder kan brukes til å disiplinere fanger.

15. Begrepet deprivasjon henspiller på at innsetting i fengsel medfører at den innsatt blir fratatt personlige ting, gjøremål, heteroseksuelle relasjoner, og blir umyndiggjort og påført utrygghet $\mathrm{i}$ forhold til medfanger, noe som fører til avpersonifisering av tidligere personlighet.

16. Irwin og Cressey 1962, s. 145.

17. Irwin og Cressey 1962 s. 145.

18. Høsten 2014 kontaktet jeg per E-post bibliotekarkivet ved Harvard University, der Wheeler arbeidet, og spurte etter dette arbeidet, men de kunne dessverre ikke finne det.

19. Wheeler (1969, s. 1020) viste til at argumentasjon som Irwin og Cresseys (1962) hadde fremført var svært nær det han selv sto for. I denne artikkelen forsøkte Irwin og Cressey å underbygge at det fantes tre fangekulturer i fengslet de skrev om, og at disse kulturene reflekterte ulike avvikskulturer i samfunnet utenfor, knyttet til forskjellige typer av kriminalitet.

20. Cline 1968, s. 182.

21. Hun undersøker forøvrig prisonisering etter samme opplegg som Wheeler(1961) med måling bare på ett tidspunkt.

22. Fravær av fangesjargong i Oslo kretsfengsel ble også bemerket av Galtung.

23. Wheeler 1969, s. 1013.

24. Bondeson 1974, s. 510.

25. Bondeson 1974, s. 201.

26. Bondeson 1968.

27. Bondeson 1974, s. 208

28. Clemmer 1958, s. 91-92. 


\section{Leif Petter Olaussen}

29. Bondeson testet Clemmers teori utenfor teoriens erklærte gyldighetsområde, minst ett år fengselstraff, og kan derfor - om man vil - anses som uinteressant for spørsmålet om teorien er holdbar eller ikke.

30. Bondeson 1974, s. 208.

31. Analysene ble publisert i Bondeson 1989.

32. Bondeson 1974 tabell 9.12, s. 209.

33. Bondeson 1974 tabell 15.3, s. 486-487.

34. Bondeson 1974 tabell 15.6, s. 490-491.

35. Bondeson 1974 tabell 15.7, s. 494-495.

36. Altså av data for ett tidspunkt, som følgelig ikke kan si noe om endringer.

37. Bondeson 1974 tabell 15.8, s. 498.

38. Se Bondeson 1974, s. 504ff.

39. Materialet var for lite til å kunne foreta en longitudinell analyse.

40. Bondeson 1989 tabell 12.1, s. 281). Hun angir ingen årstall, så man vet ikke hvilken tidsperiode tabellen dekker, og heller ikke om den dekker samme tidsperiode for alle som hun samlet tilbakefallsdata for.

41. I Bondeson 1974 tabell 15.8, s. 498 finnes en oversikt over antall personer i hver anstalt. Når denne sammenlignes med Bondeson 1989 tabell 12.1, s. 281 fremgår det at det bare er svært få i de fleste anstalter som hun manglet tilbakefallsdata for. Bortfallet er størst for interneringsanstalten Hall (17 personer).

42. Bondeson 1989, s. 281-282.

43. Bondeson 1989, tabell 12.1, s. 283.

44. Felles for undersøkelser av tilbakefall til kriminalitet og nye sykdomsutbrudd hos en pasient er at man vil undersøke om fremtidige forekomster av noe (ny kriminalitet eller sykdomsutbrudd) er betinget av et eller annet inngrep (fengselsstraff eller en bestemt behandling). I begge tilfeller er man interessert i hvor mange som «overlever» (uten tilbakefall eller nye sykdomsutbrudd) etter som tiden går etter inngrepet. Slike analyser kalles derfor ofte overlevelsesanalyser.

45. Det fremgår ikke om hun valgte ut bare alvorlig (serious) kriminalitet fra strafferegisteret, eller om registeret bare omfattet alvorlig kriminalitet og at hun tok med alt.

46. Bondeson 1989, tabell 12.6, s. 287.

47. Av den opprinnelige undersøkelsen (Bondeson 1974, tabell 15.8, s. 498) fremgår det imidlertid at det ikke var signifikant sammenheng mellom KKK og tid fangene hadde anbrakt $i$ Tillberga, og for fangene i Hall var denne sammenhengen negativ og signifikant: Jo lenger tid i anstalten, desto lavere KKK-verdi. Dette blir imidlertid forbigått i stillhet i oppfølgingsundersøkelsen.

48. I overlevelsesanalyser vil man som regel bare ha data for en avgrenset tidsperiode etter inngrepet (dette tilfellet fengselsstraffen), mens man ønsker å vite hvilken betydning inngrepet har i et lengre tidsrom. Data kalles sensurerte fordi de ikke dekker hele tidsrommet («i det lange løp») man gjerne vil vite noe om. Under bestemte forutsetninger som den britiske matematikeren David R. Cox (1972) påviste, kan man til tross for sensurerte data få pålitelige langtidsresultater om virkningen av et inngrep. Analyser som bygger på hans matematisk-statistiske forutsetninger kalles derfor ofte Cox-regresjonsmodeller.

49. Bondeson 1989, s. 288. 
50. Dette påpekes som et gjennomgående og stort analysemessig problem av Nagin, Cullen og Jonson (2009 s. 175-177).

51. De fire var Argot, theft (versus annen kriminalitet), Sent/y (det vil i dommer per år før 1970) og Recinst (det vil si antall tilbakefall i forhold til tid i fengsel).

52. Se Bondeson 1989, table1 12.7, s. 289.

53. De tre variablene var type kriminalitet (tyveri, ran eller lignende, versus annen kriminalitet), kriminalitetsbelastning før 1970 (gjennomsnittlig antall dommer per år etter fylte 16 år), og argot-kunnskap (variabelverdien ble satt til 0 hvis testresultatet i 1970 var 20 poeng eller mindre, og lik (testpoeng - 20) hvis testresultatet var 21 eller høyere. Analysen ble altså gjort på sterkt forenklede variabler. Begrunnelser for disse variabelforenklingene og drøfting av dem mangler fullstendig.

54. Bondeson 1989, table 12.10, s. 290.

55. Se Bondeson 1989, figure 12.3, s. 291.

56. Bondeson 1989, s. 292-293.

57. Nivåfeilslutning er en type logisk feil. Den er et faktum hvis man trekker slutninger om sammenhenger mellom enheter på et annet nivå enn dataenhetene i analysen, $\mathrm{i}$ dette tilfellet fra aggregatnivå (fengsler) til individnivå (fanger).

58. Se for eksempel Mathiesen 2007, s. 82-83 og Mathiesen 2011, s. 53.

59. Nagin, Cullen og Jonson 2009, s.177-178.

\section{Referanser}

Atchley, R.C. og M.P. McCabe (1968): «Socialization in Correctional Communities: A Replication.» American Sociological Review, vol 33(5) s. 774-785.

Balvig, F. (1969): «Om fangernes reaktioner på fængselsopholdet» og «Samkvem og solidatitet i fængselssamfundet», side 88-100 og side 121-165 i: Balvig, F, O. Dalå, S. Paulsen-Hansen, H. Rømer og P. Wolf (red.): Foengsler og fanger. København: Jørgen Paludans forlag.

Bondeson, U. (1968): «Argot Knowledge as an Indicator of Criminal Socialization - A study of a Training School for Girls», s. 73-107 i: N. Christie (red.): Scandinavian Studies in Criminology, vol. 2. Oslo: Universitetsforlaget.

Bondeson, U. (1974): Fången i Fångsamhället. Socialisationsprocesser vid ungdomsvårdskola, ungdomsfängelse och internering. Stockholm: P.A. Norstedt \& Söners förlag.

Bondeson, U. (1989): Prisoners in Prison Societies. New Brunswickk/London: Transaction Publishers.

Clemmer, D. (1958): The Prison Community. New York: Holt, Rinehart and Winston (Boka ble opprinnelig utgitt 1940 og utgitt på nytt i 1958, med nytt forord ).

Clemmer, D. (1950): «Observations on Imprisonment as a Source of Criminality». Journal of Criminal Law and Criminology, vol. 41, s. 311-319.

Cline, H.F. i samarbeid med S. Wheeler (1968): «The Determinants of Normative Patterns in Correctional Institutions», s. 173-184 i: N. Christie (red.): Scandinavian Studies in Criminology. Aspects of Social Control in Welfare States. Oslo, Universitetsforlaget.

Cox, D.R. (1972): «Regression Models and Life-Tables». Journal of the Royal Statistical Society, Series B 34 (2): 187-220.

Finstad, L. og A.L. Gjetvik (1980): Varetektsfanger forteller. Oslo: Universitetsforlaget.

Galtung, J. (1959): Fengselssamfunnet. Oslo: Universitetsforlaget. 
Galtung, J. (1961): «Prison: The organization of Dilemma», s. 107-145 i: Cressey D.: The Prison. Studies in institutional Organization and Change. New York: Holt, Rinehart and Winston.

Garabedian, P.C. (1963): «Social Roles and Processes of Socialzation in the Prison Community.» Social Problems, 11 (Fall) s. 139-152.

Giallombardo, R. (1966a): Society of Women: A Study of a Women's Prison, New York: John Wiley and Sons.

Giallombardo, R. (1966b): «Social Roles in a Prison for Women», Social Problems, vol. 13(2) s. 268-287.

Glaser, D. (1964): The Effectiveness of a Prison and parole System. Indianapolis: The BobbsMerrill Company.

Goffman, E. (1961/1967): Anstalt og menneske. København: Paludans fiol-bibliotek.

Irwin, J. og D.R. Cressey (1962): «Thieves, Convicts and the Inmate Culture», Social Problems, vol. 10 (Fall) s. 142-155.

Mathiesen, Th. (1965): Defences of the Weak. A Sociological Study of a Norwegian Correctional Institution. London: Tavistock Publications.

Mathiesen, Th. 2007: Kan fengsel forsvares? (3. utgave siden 1987.) Oslo: Pax forlag

Mathiesen, Th. 2011: Retten i samfunnet. En innføring $i$ rettssosiologi. (6. utgave siden 1984.) Oslo: Pax forlag.

Minke, L.K. (2012): Fcengslets indre liv. København: Jurist- og økonomforbundets forlag.

Nagin, D.S., F.T. Cullen og C.L. Jonson (2009): «Imprisonment and Reoffending», Crime and Justice, vol 38(1) s. 115-200.

Roxell, L. (2011): «Co-Offending Among Prison Inmates», The Prison Journal, vol. 91 (3) s. 366-389.

Sykes, G.M. (1958/1971): The Society of Captives. A Study of a maximum security Prison. Princeton: Princeton University Press.

Wheeler, S. (1961): «Sosialization in Correctional Communities». American Sociological Review, vol. 26 (5) s. 697-712.

Wheeler, S. (1962): «Inmate Culture in Prisons». Mimeographed report of the Laboratory of Social Relations, Harvard University. (Min kilde: Irwin og Cressey (1962, note 31 s. 153.)

Wheeler, S. (1969): «Socialization in correctional Institutions», Kapittel 25, s. 1005-1023 i: D.A. Goslin (ed.): Handbook of Socialization Research. Chicago: Rand McNally and Company, 1969. 